The impact of Qatar national professional standards: Teachers' perspectives

Romanowski, Michael H. $\bowtie$

College of Education, Qatar University, Qatar (michaelhr@qu.edu.qa)

Amatullah, Tasneem

College of Education, Qatar University, Qatar(rahimtasneem@yahoo.co.in)

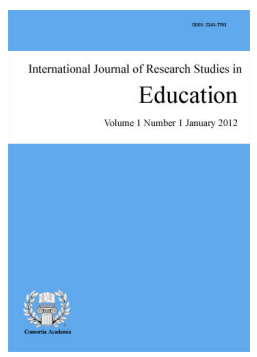

ISSN: 2243-7703 Online ISSN: 2243-7711

Received: 11 December 2013

\title{
Abstract
}

Over the past twenty years, countries have embraced educational reforms that are driven by standards-based education that include professional standards for teachers. This is the case in Qatar where professional standards for teachers where imported to improve teaching in the midst of a major educational reform. This study presents findings from 333 teachers who completed an open-ended questionnaire designed to gain teachers' perceptions and experiences with professional standards. Findings describe teachers' responses regarding professional standards as an effective framework to improve the quality of teaching and learning, the influence on instruction, the positives and negatives of professional standards and the use of standards as a tool for obtaining licensure. Discussion provides additional insight into the issues and challenges of the use of professional standards to improve the quality of instruction.

Keywords: professional standards; educational reform; qualitative research; teachers; K-12 education 


\section{The impact of Qatar national professional standards: Teachers' perspectives}

\section{Introduction}

Internationally, there is a growing body of research confirming teacher quality as one of the most important school factors influencing student achievement (Darling-Hammond, 2000, 2003; Santiago, 2002). It seems commonsense then that implementing high standards will lead to improved teaching and learning. Consequently, in the past twenty years many countries have witnessed educational reforms that are driven by standards-based education. National professional standards have influenced educational reforms in countries such as Argentina, Chile, England, New Zealand and the US with the emphasis on developing professional standards (Phillips, 1998; Hursh, 2001; Gordon \& Whitty, 1997).

Tuinamuana (2011) supports this logic arguing that national professional standards are embedded in a discourse of commonsense. That is, "having 'standards' will always be a good thing. Who would not want schools and universities to uphold professional teaching standards of some sort?" (p. 74). When it comes to educational reform, what country would not want professional teaching standards to serve as the foundation of education? Commonsense tells us that having professional standards is always a good thing because standards equal quality. Certainly the stakeholders of educational reform want to provide high quality learning experiences and to ensure that teachers strive for excellent outcomes. However, Sachs (2003) suggests, the "purpose of a commonsense view of teacher professional standards is to present an uncritical view of professional standards ... that it makes sense to put in place a regulatory framework that provides for quality, whatever that might mean" (p.177).

The issue here is that "standards and quality form the cornerstone of many national education policy developments around the world today, raising questions about the role of professional standards for teaching within these systems" (Tuinamuana, 2011, p. 72). This is the case in Qatar where professional teacher standards were implemented in 2007. However, there are clearly various controversies embedded in the development and use of professional standards raising uncertainty whether professional standards can achieve the quality of education they promise and at what cost to teachers and students (Tuinamuana, 2011). One thing for sure is that the results and outcomes of implementation of teacher professional standards do not lie in how they are written or imposed but rather how teachers make sense of these in relation to their teaching and students (Hargreaves \& Shirely, 2009).

With that in mind, the implementation of professional standards cannot simply be accepted but should be critically examined. Who better than to talk to teachers who have first-hand experience with the use of professional teacher standards? In what follows, the teachers' perceptions of the use of National Teacher Professional Standards in Qatar are presented. Specifically, their voices regarding the use of professional standards for improving the quality of teaching and learning, their perspective on the impact of professional standards on teachers, if there are any positives and negatives of professional standards and their thoughts and experiences regarding if professional standards improved the professional practices for teachers are addressed.

\section{Professional standards for teachers}

What are professional standards? A standard is 'any set of agreed-upon rules for the production of (textual or material) objects' (Bowker \& Star, 1999, p. 13). In the context of the teaching profession, standards address the practical aspects of the knowledge base of the teaching profession with significant emphasis on classroom pragmatics. They "seek to articulate what is valued about teaching and describe the critical features of what teachers know, believe and are able to do" (Mulcahy, 2010, p. 95). Standards are considered the instruments that identify the basic levels of achievement and "provide the basis for providing a benchmark of what are minimum 
levels of achievement in various aspects of their practice" (Sachs, 2003, p. 177).

Greenhough (2007) argues that standards are "a kind of knowledge defined by and through its relationships and interconnections with its wider social and environmental context" (p. 1141). In the case of professional teacher standards, they are situated within the context of teaching and classroom realities. More importantly, professional standards have power because they "do not simply describe pre-existing realities such as accomplished teaching practice or accomplished teachers; they actively produce them. They are significant participants in knowledge work" (Ewenstein \& Whyte, 2009, p. 9). Professional standards legitimize particular knowledge, dispositions, skills and conceptions of teaching and serve to create a shared and public "language of practice" (Yinger, 1987). As we know, knowledge is never neutral and professional standards are never simply a neutral collection of knowledge. McLaren (2007) argues knowledge production "is never neutral or objective but is ordered and structured in particular ways; its emphases and exclusions partake of a silent logic" (p. 196). Thus, professional standards are a set of normative statements that are negotiated within relations of power. This is particularly true in largely non-scientific fields such as educational administration (Anderson, 2001, p. 201).

The logic embedded in the professional teacher standards is a "technical" conception of teaching (Darling-Hammond, 1999). This leads to framing the teaching in the interests of law-like propositions that can be identified and manipulated. Tuinamuana (2011) argues that this type of knowledge includes an "emphasis on certainty, objectivity, the 'scientific-method' of measurement, efficiency, and control and these are transferred to understandings about education and teaching" (p. 74). When emphasis is placed on the technical effectiveness of knowledge, the end result is the reduction of 'moral, aesthetic, educational and political issues to technical problems: why and what are reduced to how' (Bullough \& Goldstein, 1984, p. 144). Questions such as: Why do we do what we are doing? Why is this knowledge being learned? ... are ignored in favor of practical concerns of 'what works'.

Mahony and Hextall (2000) ask key questions regarding standards such as, "how these terms are defined, second, by whom, and third, on how improvement of effectiveness is to be achieved" (p. 8). These questions center on important issues such as "whose interests are served by standards and the effects of the implementation of these standards on teachers" (Sachs, 2003). Standards are capable of changing the classroom, teaching and more important teachers. Furthermore, standards often require particular dispositions, habits or tendencies to act in particular ways. When teachers embrace the dispositions embedded in professional standards, these become part of their teaching or more important, their identity. Ingvarson (1998) supports this argument when he states professional teacher standards focus "on teachers as persons, where they are and what they might become, not just the present policy change" (p. 1027).

\subsection{Benefits and drawbacks of professional teacher standards}

There are several reasons for the development and use of professional teaching standards as a cure for an ailing educational system. Professional standards are equated with quality. The assumption is that if professional standards are developed and implemented, this assures that teaching will improve and in turn, student learning will increase and educational outcomes improved. Andrew (1997) states "in this era of standards, writers use the term in many different ways, seldom bothering to unpack the differences in meaning; standards become the answer to all questions; they are thought to provide the magic ingredient to restructuring all education" (p. 168). Certainly it makes good sense to put in place a regulatory framework that provides quality for the teaching profession (Sachs, 2003).

The criticism of teachers is ongoing and many aspects of this criticism call for school reform. Logically, if teachers are provided with a framework of standards by which they can exhibit professionalism and competence, the quality of teaching and teachers should increase (Thrupp, 2006). The argument is based on the notion of improvement in the quality of teaching. Ingvarson (1998) points out that professional teacher standards serve as a way to emphasize the element of teaching that teachers can be expected to use to improve their classroom 
practice. Thus, the main argument for development and use of professional teacher standards is about change, improvement of teaching and educational outcomes.

Another argument is that professional standards provide accountability for teachers to the stakeholders in education. This will potentially represent a level of quality. Professional standards center on outcomes and performances that attempt to hold teachers professionally accountable because they "are expected to acquire specialized knowledge, meet standards for entry, and uphold professional standards of practice in their work" (Darling-Hammond, 2004, p. 1050). Accountability is based on outcomes and results and by definition, professional standards provide a framework or criteria that teachers can use as a measure of their accomplishments and a way of providing evidence to stakeholders of their achievements and accreditation (Sachs, 2003).

An uncritical look at the use of professional standards suggests that standards solve educational problems and are in the best interests of teachers, students and the teaching profession. However, there are certainly drawbacks and criticisms of the development and use of professional standards. Darling-Hammond (1999) notes some cautions about teaching standards, "teaching standards are not a magic bullet. By themselves, they cannot solve the problems of dysfunctional school" (p. 39). First, Mcdaid, (2010) points out that there is a major contradiction that is embedded in the development and use of professional standards. Most educators would agree that it is important to create teachers who are autonomous reflective practitioners but there is an argument that professional standards attempt to deskill teachers by regulating what and how they teach through increase reliance on standards and accountability measures. This in turn reduces teachers to technicians. That is, simple technicians: uncritical, objective, and efficient distributors of information who neglect the more critical aspects of culture and schooling (Giroux \& McLaren, 1996, p. 304). Eliminated from teaching are the important political, social, ethical and educational issues in favor on the pragmatics of how to and what works. Kostogriz (2007) argues this has been evident in other Western countries that have embraced standards based designed to keep teachers accountable.

Second, Thrupp (2006) thinks that the public and professional appeal of teaching standards may be politically exploited and may serve as a way of controlling teachers. He argues that specified professional standards have a much greater capacity to "control and contain teachers" (p. 3). Basically, standards control what and how teachers teach. This control is accomplished "by intensifying their workload resulting in few improvements in teaching quality as teachers could fabricate evidence in order to jump through hoops to meet requirements" (Mcdaid, 2010, p. 782). Sachs (2003) termed the use of standards as a "government imposed regulatory framework" (p. 185) over the teaching profession. Professional standards control teachers by emphasizing the perspective of the standard creators over those of the teacher. Zuzovsky and Lipman (2006) concluded that, "the value of standards is not questioned. What is questioned is their imposition as controlling devices" (p. 48).

Third, Kleinhenz and Ingvarson (2004) maintain there is a real concern that teachers may not see the value of standards that might lead to disconnectedness because the standards are seen as top down and bureaucratically conceived. The bureaucracy creates additional work and it is often the case that teachers become "overburdened with guidelines and standards to which they must measure and provide evidence of their accomplishments within their profession rather than engage in the business of education" (Mcdaid, 2010, p. 780). Furthermore, these controls standardize teaching practices instead of building teachers' knowledge that can be adapted and applied to different subjects, the social context, the community or the individual needs of children (Darling-Hammond, 1999). Sachs (2005) argues that standards remove "professional autonomy, engagement and expertise away from teachers, reduce diversity of practice and opinion and promote 'safe' practice" (p. 3-4).

Finally, imported professional standards are granted authority by the government and school authorization and are given legitimacy by simply the fact that the commodities are imported from Western educational experts. This authority places the knowledge beyond criticism, and imposes it on educational leaders as a body of 
objective knowledge. Giroux (1988) argues that privileged knowledge like that of professional standards is treated, "as something external, knowledge is divorced from human meaning and intersubjective exchange. It no longer is seen as something to be questioned, analyzed, and negotiated; instead, it becomes something to be managed and mastered" (p. 14).

Since professional standards are usually unquestionably accepted as a tool for the improvement of education, it is important to critically examine professional standards for teachers. Mahony and Hextall (2000) argue when examining standards it is important to look at values, principles and assumptions but also they should be questioned in "terms of the manner in which they are translated into practice and the consequences, both manifest and latent, which follow"(p. 30). With that in mind, this study examines Qatar professional teacher standards from the perspective of teachers centering on what is the impact of Qatar's professional teacher standards on teachers and the classroom and as teachers, what are their thoughts and experiences working with professional standards?

\section{Background}

In 2001 because of the concern for secondary students' lower scores in the Trends in International Mathematics and Science Study (TIMSS) and the Programme for International Assessment (PISA), the Qatari government grew concerned about the outcomes of the country's educational system. The fear was that Qatar's educational system was not situated to produce the necessary outcomes for the future development of Qatar. In an attempt to reform the system, the government approached RAND, a nonprofit research organization to investigate the Qatari educational system and provide recommendations and options that would serve as a framework for reforming the entire school system. As a result of RAND's report, a systematic reform designed to convert Qatar's schools into a competitive educational system known as Education for a New Era (EFNE) was initiated and is recognized as central to the development of the Qatari economy.

Education for a New Era is based on a key standard that is "no matter what else was to occur, the basic educational elements of a standards-based system had to be put in place" (Brewer, et al. 2007, p. xviii). Consequently, National Curriculum Standards for English, Science, Math and Arabic were developed. These were accompanied by Qatar National Professional Standards for School Teachers and Leaders (QNPSTSL), ${ }^{1}$ a set of professional standards for teachers and administrators that provide common reference points for educators developing their careers at Qatari Independent Schools (Supreme Education Council, 2007). QNPSTSL describe the skills and knowledge necessary for effective teachers and school leaders and provide a "framework to describe tasks and professional development throughout the career of teachers or leaders. This will improve their participation in Qatar's education reform initiative, which in turn improves the students' learning quality" (Supreme Education Council, 2007, p. 14). To ensure a successful implementation of the reform, the Supreme Education Council plays an integral part in ensuring that teachers are performing according to national professional standards and offers professional development for teachers based on the professional standards.

\subsection{Qatar national professional standards for teachers}

Qatar National Professional Standards for School Teachers and Leaders (QNPSTSL) is a document containing 12 professional standards for teachers and 7 professional standards for school leaders developed by Education Queensland International (EQI) of Australia. In 2006, EQI met with stakeholders in the Qatari Independent Schools and discussed the development of standards with different institutions, universities, School Support Organizations and officials involved in the Diploma of Primary Education, offered by Qatar University and Texas A\&M (Supreme Education Council, 2007). The purpose of these meetings was to gain input for the development of standards and the results was the development of the QNPSTSL. According to the Supreme Education Council, the QNPSTSL were “developed taking into account the real education environment in Qatar

\footnotetext{
${ }^{1}$ QNPSTSL includes standards for both teachers and school leaders. For this paper, QNPST is used when addressing the professional standards for teachers.
} 
Romanowski, M. H. \& Amatullah, T.

and the goals of the reform initiative" (Supreme Education Council, 2007). EQI states that the standards provide "a common reference point to describe, celebrate and support the complex and varied work of teachers and school leaders in the new Independent Schools" (Qatar National Professional Standards for Teachers and School

Leaders, 2007, p. 1).

\section{Table 1}

Qatar National Standards and Statements Teachers

\begin{tabular}{|c|c|}
\hline Standard & Statements \\
\hline $\begin{array}{l}\text { 1. Structure innovative and flexible } \\
\text { learning experiences for } \\
\text { individuals and groups of } \\
\text { students }\end{array}$ & $\begin{array}{l}\text { 1.1 Identify learning goals that reflect curriculum documents and school policies. } \\
\text { 1.2 Incorporate information on students in the design of learning experiences. } \\
\text { 1.3 Plan for students with special learning requirements in the design of learning experiences. } \\
\text { 1.4 Select innovative and flexible teaching and learning strategies to maximize student learning. } \\
\text { 1.5 Implement flexible and innovative learning experiences. } \\
\text { 1.6 Review and evaluate learning experiences. }\end{array}$ \\
\hline $\begin{array}{l}\text { 2. Use teaching strategies and } \\
\text { resources to engage students in } \\
\text { effective learning }\end{array}$ & $\begin{array}{l}\text { 2.1 Use a variety of teaching and learning strategies to engage students in effective learning. } \\
\text { 2.2 Use a range of teaching resources to engage students in effective learning. } \\
\text { 2.3 Evaluate the effectiveness of teaching and learning strategies and resources. }\end{array}$ \\
\hline $\begin{array}{l}\text { 3. Foster language, literacy and } \\
\text { numeracy development }\end{array}$ & $\begin{array}{l}\text { 3.1 Critically review personal Arabic and English language, literacy and numeracy skills. } \\
\text { 3.2 Determine students' language, literacy and numeracy skills to inform the planning and } \\
\text { implementation of learning experiences. } \\
\text { 3.3 Integrate language and literacy development across all teaching/subject areas. } \\
\text { 3.4 Integrate numeracy development across all teaching/subject areas. } \\
\text { 3.5 Monitor and evaluate students' language, literacy and numeracy development. }\end{array}$ \\
\hline $\begin{array}{l}\text { 4. Create safe, supportive and } \\
\text { challenging learning } \\
\text { environments }\end{array}$ & $\begin{array}{l}\text { 4.1 Create safe and supportive learning environments. } \\
\text { 4.2 Provide learning environments in which students have responsibility for their own learning. } \\
\text { 4.3 Provide learning experiences in which students engage in purposeful and intellectually } \\
\text { challenging learning experiences. } \\
\text { 4.4 Provide learning experiences in which students use higher-order and critical thinking skills. } \\
\text { 4.5 Provide learning environments in which students learn to take responsibility for their own } \\
\text { behavior }\end{array}$ \\
\hline $\begin{array}{l}\text { 5. Construct learning experiences } \\
\text { that connect with the world } \\
\text { beyond school }\end{array}$ & $\begin{array}{l}\text { 5.1 Devise learning experiences that build on students' prior knowledge, life experiences and } \\
\text { interests. } \\
\text { 5.2 Engage students in learning experiences that integrate ideas, concepts and information across } \\
\text { teaching/subject areas. } \\
\text { 5.3 Provide learning experiences that establish connections with the world beyond the classroom. } \\
\text { 5.4 Develop learning experiences that involve students in examining study, work and leisure in the } \\
\text { future. } \\
\text { 5.5 Design learning experiences that foster personal initiative and enterprise. }\end{array}$ \\
\hline $\begin{array}{l}\text { 6. Apply ICT in managing student } \\
\text { learning }\end{array}$ & $\begin{array}{l}\text { 6.1 Determine students' ICT learning needs. } \\
\text { 6.2 Select appropriate ICT-based learning strategies and resources. } \\
\text { 6.3 Create learning experiences that actively use ICT to organize, research, interpret, analyze, } \\
\text { communicate and represent knowledge. } \\
\text { 6.4 Use ICT in the assessment of student learning. } \\
\text { 6.5 Evaluate ICT-based teaching, learning and assessment approaches. } \\
\text { 6.6 Use ICT to access and manage information on student learning. }\end{array}$ \\
\hline $\begin{array}{l}\text { 7. Assess and report on student } \\
\text { learning }\end{array}$ & $\begin{array}{l}\text { 7.1 Establish learning goals and assessment requirements. } \\
\text { 7.2 Plan assessment. } \\
\text { 7.3 Conduct assessment. } \\
\text { 7.4 Provide feedback on assessment outcomes. } \\
\text { 7.5 Review assessment. }\end{array}$ \\
\hline $\begin{array}{l}\text { 8. Apply knowledge of students } \\
\text { and how they learn to support } \\
\text { student learning and } \\
\text { development }\end{array}$ & $\begin{array}{l}\text { 8.1 Use information on students to support learning. } \\
\text { 8.2 Support students in developing personal identity, self-esteem and a positive self-image. } \\
\text { 8.3 Assist students to develop empathy with others. } \\
\text { 8.4 Engage students in assessing and planning their personal futures. } \\
\text { 8.5 Provide care and support for students. }\end{array}$ \\
\hline $\begin{array}{l}\text { 9. Apply teaching/subject area } \\
\text { knowledge to support student } \\
\text { learning }\end{array}$ & $\begin{array}{l}\text { 9.1 Acquire and maintain teaching/subject area knowledge. } \\
\text { 9.2 Apply knowledge of curriculum documents and support materials to enhance student learning. } \\
\text { 9.3 Apply teaching/subject area knowledge to enhance student learning. }\end{array}$ \\
\hline $\begin{array}{l}\text { 10. Work as a member of } \\
\text { professional teams }\end{array}$ & $\begin{array}{l}\text { 10.1 Meet personal work-related goals and priorities. } \\
\text { 10.2 Contribute to professional teams. } \\
\text { 10.3 Work with others to maximize student learning. } \\
\text { 10.4 Contribute to improving the performance of professional teams. }\end{array}$ \\
\hline $\begin{array}{l}\text { 11. Build partnerships with families } \\
\text { and the community }\end{array}$ & $\begin{array}{l}\text { 11.1 Build relationships with families and the broader community to enhance student learning. } \\
\text { 11.2 Establish learning environments that acknowledge students' families and communities. } \\
\text { 11.3 Promote school and Supreme Education Council education reforms. }\end{array}$ \\
\hline $\begin{array}{l}\text { 12. Reflect on, evaluate and } \\
\text { improve professional practice }\end{array}$ & $\begin{array}{l}\text { 12.1 Reflect critically on professional practice. } \\
\text { 12.2 Engage in personal and collegial professional development. } \\
\text { 12.3 Contribute to learning communities and other professional networks. } \\
\text { 12.4 Participate in school governance. } \\
\text { 12.5 Meet ethical, accountability and professional requirements. }\end{array}$ \\
\hline
\end{tabular}


The Professional Standards for Teachers describe the capabilities that teachers need to provide challenging and rewarding learning experiences for students (Qatar National Professional Standards for Teachers and School Leaders, 2007 , p. 3). The standards require teachers to focus on learning experiences and approaches to instructions such as cooperative or group learning, the use of ICT, assessment, knowledge of students and subject areas, school-community relations, and to engage in reflection to improve practice. The standards are a set of statements that do not specifically define terms or concepts but leaves the reader or more likely, an authority figure to interpret meanings.

In addition to the above elements of the QNPST, there are 12 Standard Descriptors that provide a brief description of the aspect of professional practice covered by the standard. Also included are 55 standard statements, 235 Standard Indicators that identify the actions a teacher would normally take to perform the aspect of professional practice detailed in the relevant statement. In addition, the required skills, knowledge, understandings and dispositions that underpin the professional practice are described in each standard. These include 73 required skills, 199 statements of required knowledge and 59 required dispositions. Finally, an evidence guide is provided identifying the performance expected of teachers at each stage of career development; entry level, proficient and advanced skill teachers. The evidence guide also includes a list of the types of evidence that demonstrates the achievement of the particular standard. These professional standards were applied in the 2007-2008 academic year with the goal of providing a framework for teachers and school leaders to shape curriculum, daily lessons and guide the leadership of school.

Currently, the professional standards also serve as the foundation for obtaining a teaching license in Qatar. Teachers were provided extensive educational workshops designed to introduce the professional standards and develop teachers' skill to utilize these standards in the classroom. Also, teachers, with the help of a coach (another colleague working in the same school), must complete a portfolio where they include evidence of good practice. Each piece of evidence is linked to a particular standard in the QNPSTSL and includes a written narrative that expresses how and why the selected evidence meets the given standard. When complete, the candidate submits the electronic portfolio to his or her schools' Attestation Committee. Obtaining a complete license implies that the candidate has attained the knowledge and skills to the level required by the QNPST (Online Qatar, 2009).

\section{Research methodology}

While professional teacher standards serve as the cornerstone for standards-based educational reforms, teachers determine the realization of professional standards. Therefore, there is a need to study the influence of standards on teachers in order to contribute to a better and unique understanding of the impact of professional standards. However, few studies have directly examined teachers' perspectives on the use of professional standards. In this study, 333 teachers teaching in Qatar's Independent Schools responded to an open-ended questionnaire designed to elicit their experiences working with the QNPST and their perceptions of the effectiveness of the standards, the influence of the standards on their teaching, the positives and negatives of the aspect of the current use of the standards, and if the standards are helping to improve the professional practices for teachers.

\subsection{Research methods}

Since all teachers in independent schools in Qatar are held accountable to the QNPST, any teacher who teaches in an independent school in Qatar could respond to the survey. Teachers in the graduate programs at Qatar University were asked to complete the surveys and then to request their colleagues in their schools to complete the survey. In addition, the survey was sent to teachers that the researchers' colleagues knew stating that the survey needed to be completed for research purposes. These individuals were encouraged to pass the survey on to other teachers. The survey was also circulated through social networks such as What's App, Blackberry Messenger and text messaging. Thus, the sample for this study was randomly drawn from teachers in independent schools in Qatar. The research questions are as follows: 
1. From the perspective of teachers in independent schools, does the Qatar National Professional Standards for Teachers (QNPST) provide an effective framework for improving the quality of teaching and learning?

2. What do teachers in independent schools see as the impact of QNPST on their teaching?

3. What do teachers in independent schools see as the positive and negatives of QNPST?

4. From the perspective of teachers in independent schools, has the QNPST improved the professional practices for teachers?

An open-ended questionnaire was designed to examine respondents' perceptions and use of QNPST. Participants were asked to complete the eight question open-ended survey posted on Survey Monkey (Available in both English and Arabic). The instrument was initially written in English then translated into Arabic and judged for the quality of the translations by bilingual native Arabic speakers. Face validity was obtained by having two bilingual professors who are well qualified in conducting research examine the questionnaire and determine if the questionnaire in the Arabic translation was accurately asking participants to discuss their perceptions and experiences with professional teacher standards. Regarding the exploratory nature of the study, open-ended questions were more appropriate for the purposes of this research. While closed questions allow to collect data that can be analyzed statistically and yield generalizable results, the narrative comments from open-ended questions provide a forum for explanations, meanings and new ideas that allow to describe a phenomenon as lived and perceived by the respondent (Cohen, Manion, \& Morisson, 2007).

\subsection{Sample information}

For this study, 333 teachers teaching in independent schools in the Qatar responded to an eight-item survey. Of these respondents, the average number of years teaching was 7.94 with a range of 5 months to 25 years. The sample included 67 primary school teachers, 17 preparatory school teachers, 13 secondary school teachers and 236 that did not define the level they taught. However, all teachers in independent schools are under the same professional standards. The average number of years that the sample worked under/with the Qatar National Professional Standards for Teachers was from 5.15 years ranging from 5 months to 7 years.

\section{Findings}

These findings present the perspectives of teachers who have been using the professional standards to guide their teaching practices. At times, their responses are not supported with comments but are simply a yes or no answer. However, the yes/no responses provide an idea of the percentages of the participants' views on particular issues and the responses that included comments provide in-depth understandings about the use of professional standards. Nevertheless, this research provides a snapshot of teachers' thinking about the use of the Qatar Professional Standards for Teachers.

\subsection{National professional standards as an effective framework}

Findings from the questionnaire responses indicated that 37\% (121 participants) believed that National Professional Standards for Teachers provides an effective framework for improving the quality of teaching and learning. However, 50\% (168 participants) presented an opposing view and 13\% (44 participants) of the responses deviated from the question.

Those who indicated a positive opinion viewed the standards as an effective framework because it improved the quality of teaching and learning by systemizing the teacher's role, improved professional practices and encouraged teachers to focus on the main factors of the educational process; family, school, and society. This thinking regarding how standards serve as an effective framework is illustrated by one participant who wrote: 
The impact of Qatar national professional standards: Teachers' perspectives

Yes, I believe the national standards for teachers have basic requirements to improve teaching and learning qualities because it provides the knowledge, skills and opportunity for the teachers to take challenges in this process.

Several participants highlighted that standards help them set goals to achieve that are evident in their teaching portfolios while others argued that standards act as an assessment tool for teachers to reflect and evaluate their work.

Another reason that was evident in participants' responses was the improvement of education. One participant wrote: "These standards are of high quality and are developed to keep pace with the rapid development in education worldwide". Another participant sums up the idea by stating "Understanding the national standards will lead to an extensive enrichment in the quality of education".

However, there are a significant number of teachers who argued that the standards do not really serve as an effective framework. The majority of these indicated that most of these standards are not clear, confusing, impractical and repetitive. One respondent stated "They're [the standards] are unclear and repeated and some are not even beneficial". This is echoed by another participant who wrote "most of these standards are unclear and the understanding of them, varies from one teacher to another". Some respondents justified their thinking that standards were not useful saying they were adopted not adapted and poorly translated to Arabic. Additional written comments provided insight into other viewpoints.

Standards basically kill the teacher's creativity

Because the teachers are now focusing on the standards and not the teaching process

The standards do not test teaching ability. Rather, they test the teacher's ability to document how they meet standards ... teachers often make up evidence of applying those standards in order to get higher evaluation.

Because the teacher focuses on applying those standards without actually evaluating their effectiveness on student's performance

These statements reflect how teachers view standards as demotivating the teaching process. Some respondents merely viewed the standards as a tool for professional documentation. This was represented in the thoughts below: "The teachers are now concerned about collecting evidence of applying the standards, forgetting their main role as educators" and "They have a negative impact as the teachers focus on preparing the portfolio and disregard the teaching process".

Furthermore, some participants emphasized the importance of national standards in the field of education yet, they expressed their thoughts of being trained for implementation. One woman wrote: "I think the national professional standards are highly beneficial once a teacher knows exactly how to implement them in their teaching methods". This thought is mentioned by other participants who stated "They are somehow effective but there are still a high percentage of teachers who do not know how to use them", "They need to be clarified to the teachers to be able to implement them in classrooms" and "Majority of teachers do not understand the concept of National Standards and haven't received the necessary training to be able to apply them".

\subsection{Professional standards and the quality of teachers' classroom practices}

When responding to the issue that the QNPST reflect the quality of teachers' practices and work inside the classroom, $20 \%$ of the participants agreed that there was a direct link between the standards and classroom practices while the majority $71 \%$ disagreed. The remaining participants seemed to indicate partial agreement using the term "sort of' to describe the relationship between standards and classroom practices. Sixty-nine of the $20 \%$ of participants who thought the QNPST impacted the quality of teaching provided little support for their 
position. However, five participants defended their opinion by stating standards improved their teaching practices and one participant related the standards to student achievement. On participant wrote:

The professional standards care about preparing a supportive and effective environment between the student and teacher that raises the morale of the student that leads him to progress academically and be more creative.

The majority who did not agree with the idea of QNPST improving classroom practices, roughly $73 \%$ limited their answers to 'no' whereas $27 \%$ of the participants supported their position. Sixteen participants argued that the quality of teaching practices comes through experience and the effort they put and not by making portfolio and that the QNPST are just a benchmark to organize their teaching. Participants wrote:

A quality teacher will be successful even if he/she follows the standards or not.

The experienced educated teacher would learn from mistake and following directions from coordinator and academic supervisor which plays a big role in development of the teacher in the classroom and standards just serve as laws to organize.

Similar thoughts were echoed by sixteen participants who argued that standards demand teachers merely to make portfolios by collecting evidences for each standard that uses most of the teachers' time; while interrupting them from educating students. Responses that illustrated these thoughts are stated below:

There is no connection because the teacher focuses on how to prove and document their work in the classroom that deviate them from students and educational process as such. Principals'judge through pictures and papers only, they don't follow up student's progress.

The teachers waste most of their time in understanding the standards, they are vague; the time that should be devoted to students

Eight participants thought that QNPST do not reflect the quality of teachers' practices rather the process gives space for teachers to falsely prepare evidences for the sake of documentation for the portfolio. The following participant's comment illustrates this argument.

If the teacher understands the standard well and applies it in the classroom then it contributes to quality teaching, if not, all their thinking is to create an evidence for the portfolio, copy from his colleague without understanding the standard.

There were a few teachers who argued for the past stating that before the implementation of standards and therefor, teaching was effective and that was evident in the students' achievement. One participant commented, "From my perspective, I would say that some teachers still follow the ministry of education teaching policies and their students' level is high". Another participant strongly supported this thought stating, "The quality was better, now the teacher is working on documentation of work, not centering on students as before rather the satisfaction of the manager in SEC (Supreme Education Council) is more important".

\subsection{Influences on teaching}

Regarding teachers' perspectives on the influence of the QNPST on teaching, a variety of positive and negative themes emerged. Thirty-seven percent of the teachers believe that there is a positive influence of QNPST on their teaching while $32 \%$ argued that the standards had negative aspects. Finally $31 \%$ stated there is no significant influence of standards on their teaching. Themes such as teaching strategies (46 participants), technology (12 participants), communication/community involvement (11 participants), differentiated teaching strategies (10 participants) and becoming more organized and goal oriented (14 participants) emerged with respect to the positive influence of the QNPST. The following respondents' comments sum up these influences. 
The second standard encourages using variety of resources for teaching like the internet \& flash cards which attract the students.

Organized activities and made it goal oriented, also to care about students \& their family opinions in the educational process and provide feedback.

Developed our teaching methods and the use of technology

The national professional standards improved my communication skills with society, institution and parents.

Using differentiated teaching strategies to improve education learning differences.

These statements clearly present the positive influence of standards that enabled these teachers to enhance their professional practices and meet students' needs.

However, there were participants (32\%) reporting the negative influence of standards on their teaching. Thirty participants argued that standards overloaded them with extra work that creates stress and tension whereas, 36 respondents argued that the amount of time invested in meeting the standards was the demanding element that deviated teachers from real purpose of educating students. One participant wrote, "The truth is these standards negatively affect the teacher's performance, it distracts my efforts and the student no longer is at the center". Another participant stated "It creates pressure and make the teaching career difficult". One participant summarized this idea, "standards made teaching more complicated, it takes long time to prepare files with evidences for portfolio that demands my time, my students' time, my family time and my health". Finally, the participants who argued that there was no influence of standards on their teaching stated the standards "did not affect, because the teachers' practices and quality of teaching is the same and we learn it from teaching experience", and "I taught 13 years and standards didn't change anything in my teaching".

\subsection{Are national standards positive for Qatar's educational reform?}

Concerning the idea of adopting a set of national standards for teachers in order to aid in Qatar's educational reform, $97 \%$ of the participants appropriately responded to this question and roughly $38 \%$ of these responses were limited to yes or no without any support for their position. However, $61.6 \%$ of the participants provided support for their responses with $30 \%$ arguing that professional standards are a positive aspect of the reform. Participants wrote:

Yes, because the 12 standards are aimed to improve education in Qatar at all levels.

They encourage self-learning and scientific research and promote the idea of the student being the center of the educational process.

They are very affective for education reform.

Several participants reinforced the positive impact of QNPST on the educational reform stating the standards serve as foundation of education and teaching practices. This was reflected in several comments:

They (standards) are comprehensive and are on pace with the educational development worldwide.

They force the teachers to use new teaching strategies.

They are (QNPST) the basis for education.

Yes, they have a great influence on education. 
One participant clearly communicated her thinking regarding QNPST and the educational reform in Qatar "I think the standards are positive, because if a teacher honestly follows the QNPST and implements those in the teaching and learning process then definitely there will be a positive change in Qatar Education Reform". Eighteen (5.5\%) participants presented positive viewpoints on the impact of the QNPST and also offered suggestions for improvements.

It was a positive initiative. I think it would be successful if they were first applied in an excellent school and a good staff to evaluate the standards fairly.

Yes, of course. They just need to be understood correctly in order to be effective.

Yes, but the application needs to be more flexible.

As a whole, these statements demonstrate that participants believe that the standards have potential but there is some improvement required and the use more flexible in order for successful implementation.

The majority of the participants (70\%) responded negatively arguing the QNPST are not an essential element of Qatar's educational reform. Thirty percent of the participants provided reasons such as low student achievement, lack of training, time involved, more paper work, a burden on teachers, deviates from teaching and added that standards are complicated and it is difficult to understand. The following participants' comments illustrate these issues:

The huge number of failing students proves the failure of the adoption of professional standards

Teachers are not trained on the implementation of the standards.

It could have been of positive impact if it did not consume the teacher's time in preparing evidence and paper work

They just make the teachers tired and make them forget the main point of education.

They make teachers focus on paper work more than on teaching.

Eleven participants argued that the standards are too complicated in structure and it complicates the teaching and learning process itself. Participants wrote: "They are too complicated", "Standards are hard to understand. It is better to teach the standards to teachers before getting to schools", and "They complicated the process of teaching and learning". There were a few participants who believed that the education in the past was better because of the implementation of the standards. Overall, there is little support that the professional standards are a positive element of the current educational reform.

\subsection{Overall positives and negatives of QNPST}

Participants indicated both positive and negative aspects of the QNPST. Sixty-one percent of the respondents indicated there were positive aspects, while $26.5 \%$ reflected on its negative aspects and $12.5 \%$ stated their opinions on both the positive and negative elements. Those who identified the positive aspects of the standards stated the imperative role that professional standards play in the field of education. The following participants' comments illustrate this argument.

Teachers have a better understanding of what they should do to improve their performance and teaching skills ... they need to know to be a better teacher

Standards are a reference for teachers to make the educational process work in terms of determining the objectives of a respective lesson.

Organizes thoughts that help determine objectives of a lesson 
These statements emphasize the impact standards have on teacher's professional development by indicating that standards may help in developing a teacher's skills, improving organization of teaching activities and encouraging professional reflection.

Eighty-one percent of participants identified negative aspects of the QNPST. Fifty-five teachers (18.7\% of participants) centered their points on the time involved to meet the standard rather than the standards themselves.

Good in terms of making teachers rethink their performances and evaluate them yet time constraint is a problem.

A waste of teachers' time; those standards are a key to evaluating teachers' performance, which I believe is not fair because a good teacher can be seen through parents' impression of them as well as their managers' evaluation".

Puts pressure on teachers with the time constraint, the students are no longer the center of attention.

Moving beyond the argument regarding time, participants thought there were too many standards and many appeared repetitive. One participant stated, standards are "good in terms of proving achievements but the problem lies in the number of standards" while another thought it was "difficult to understand Standards especially that they are changeable and difficulty to keep record of achievements, so it is a waste of time in general". Another teacher stated the standards "are a positive idea but Standards are kind of repetitive".

A key issue that often surfaces when Western educational products are adopted into the GCC educational system is translation. This was the case with these teachers who often linked the difficult use and understandings of the standards to poor English to Arabic translation. Several respondents argued standards are poorly translated into Arabic and this causes confusion among teachers reducing their understanding of what the standards means and requires. Participants stated the standards are carefully studied and clear but the literally translation into Arabic creates problems and there is only a literary translation from another languages and this is a clear limitation.

Finally, another important issue for teachers is that working with standards takes time away from their teaching and because standards are used for licensure through the development of a comprehensive portfolio, many believe their teaching and students suffer. For example, one participant wrote: "It reminds teachers of doing their job properly but they hardly benefit students", "Teachers focus too much on professional standards and lose sight of their core job; students" and "Standards make teachers lose sight of focusing on students. They teach just to fill in their portfolio with the so called achievements". Other participants indicated similar thoughts,

It helps improve the professional portfolio for teachers and creates more interactions between students, teachers and external environment yet it confines teachers in the sense that the only concern is getting papers filled in, not paying attention to students as essential part of the educational process

It helped me a lot in self-improvement and in giving me the teaching license yet the difficulty lies in collecting information and examples for the professional portfolio

Overall, the majority of the participants express negatives to the adoption of the QNPST; while several respondents provided positive outcomes that were worth mentioning.

\subsection{Teaching license and portfolio}

A small minority of the participants (18\%) indicated the development of the portfolio, that is required for the licensure process, actually reflects classroom application of QNPST. From those who provided support for their position, two main aspects credibility and the implications were the focus. These participants believed the 
standards were reflected in the portfolio if the portfolio was constructed in a manner that had credibility in meeting the requirements of portfolio. Participants explained, "Yes, if there is credibility in creating it". Another participant who had similar thoughts wrote, "Yes, if the evidence were real". With regards to the implication of QNPST one respondent argued, "Yes, if the standards were explained to the teachers and if the portfolios were evaluated more professionally". What is being communicated here is that the large majority of teachers who develop portfolios might not really the practice what is presented in the portfolio but rather just provide evidence to meet the standards. Several teachers argued that the evidences in the portfolios were not genuine and made up most of the time by teachers. The following respondents' comments illustrate this argument.

The portfolio cannot be a reflection of the standards as there is not a belief of its importance thus, teachers make up evidence to avoid tension with the school's authority.

Teachers are faking the evidence and the portfolio is actually testing the teachers abilities in documentation and not application.

Most of the evidences are fake and what's worse is that some teachers ask the students and the parents for a "thank you" letter to include to their portfolio that is pretty degrading in my opinion.

Teachers are now focusing on collecting evidences. They would list books as references when they haven't used any of them in their lessons.

These statements clearly reflect the respondents' negative attitude towards the portfolio as a means of reflecting the standards.

There is an argument that developed in these participants' responses. Participants argued that the portfolio does not cover all the efforts of teachers and it is far beyond the reality of what happens in the classroom. One participant wrote, "We would apply standards in a better way if we did not have to prepare the portfolio". Another participant echoed similar thought stating, "It is not a reflection because some of what is in the portfolio is far from reality". One participant argued the teaching and learning process should focus on students learning more than teachers.

The remaining participants centered their views on various elements such as time, effort, distraction, and demotivation. Responses that illustrated these thoughts are stated below:

The teachers need to be using the time they have to come up with different, creative ways to deliver the lesson to the students instead of wasting their times taking photos of the students to add to the portfolio as evidence.

It (portfolio) distracts the teachers from their real job.

Standards affect teachers negatively as they became demotivated to work anymore.

Although the majority of participants responded negatively to the idea that the portfolio reflects the QNPST, their views centered on similar thoughts as previously discussed in the positives and negatives of QNPST.

\subsection{Standards improving teaching practices}

Forty percent of the participants were positive that the QNPST improved their professional teaching practices. The support for this belief centered on helping them to construct lesson plans and providing various teaching strategies. One participant stated, "As a beginner with not enough experience it help with teaching methods and educational strategies". Others argued the QNPST helps new teachers improve their teaching practices, "It would help them improve their professional practices and skills", and "It is suitable for new teachers, they can benefit from standards to improve their teaching abilities". Finally, several teachers support 
The impact of Qatar national professional standards: Teachers' perspectives

their viewpoint presenting the idea that the standards help new teachers to set goals and achieve the goals.

The views of the participants who responded negatively centered on the themes of time, unclear and difficulty in understanding, standards as a burden to teachers and the extensive efforts needed to develop their portfolio. The following respondents' comments illustrate these arguments.

The QNPST aren't helping to improve the professional practices for teachers, they need more time to learn and comprehend it.

It [standards] does not provide anything new and most of it is not clear in understanding.

The portfolio distracts the new teacher and restrict in personal development, causes pressure on teachers deviating from their main job

Beyond these issues, 31 participants raised the concern of the lack of proper training for teachers irrespective of whether they agreed or not with idea of QNPST helping teachers. Participants wrote, "Teachers should be provided with required training to understand QNPST in right way", "If these standards are shortened with detailed explanation, it will help", and "it will be excellent for new teachers to take intensive courses on standards before starting their job".

\section{Discussion}

There is little doubt that we desire high standards for teachers so they are better equipped to teach and in turn improve student learning. Furthermore, we want teachers, who are critical thinkers able to critically reflect on their professional practices, make adjustments to their teaching and improve learning. However, based on these findings from the teachers' perceptions, there are concerns that these professional standards are not providing the quality and having the positive impact intended. Findings necessitate several issues that need to be discussed.

First, there is a concern of the lack of support that participants provided regarding their arguments for or against standards, but more importantly, when support was provided, the discussion seem to lack substantial academic or educational discourse. The large majority of participants seem to justify their responses with personal feelings and thoughts and often general and vague statements. For example, the idea that the large student failure rate is proof that professional standards are not effective is quite simplistic. This idea does not take into account, the newly implemented curriculum standards, standardized testing, the current shift in the language of instruction and a whole host of other factors that influence students learning and outcome. It often seemed that the academic arguments were missing and more concern was placed on personal issues such as time or paper work rather than a discussion about the educational value of professional standards. In addition, some of the claims by these participants might not be academically sound.

The quotes provided in this paper represent the better participant responses but still, the majority of the participants' responses lacked significant support. This issue could be related to the lack of qualifications that hampers teachers in Qatari Independent Schools. According to the Supreme Education Council (2011), more than $30 \%$ of teachers in Qatar are not qualified to teach; 31\% of teachers in Qatar have no formal qualifications to teach, $35 \%$ of who are teaching in independent schools. This is evident in this study when teachers argue that the standards are too complicated, hard to understand and that professional standards complicated the teaching and learning process.

Second, another issue is the narrow vision of standards that is illustrated by many of the participants. The majority of the respondents seem to limit their view of the role of the QNPST to providing evidence of their ability to achieve the particular standards in order to receive their licensure. For many of the participants when it comes to professional standards, there seems to be a bifurcation where the standards are separated from the actual classroom practice. For the majority of the participants, the standards are simply there for them to gain 
licensure by developing a portfolio that provides evidence that they have achieved each standard. This is problematic in the sense that standards are not fully embraced and integrated within teaching but reduced to an exercise to achieve a particular end.

Third, for many of these participants, there seems to be somewhat of an obsession with the standards that takes away from other important aspects of teaching. It seems that instead of the standards serving teachers to aid in their professional development and teaching, teachers are serving the standards, often times in superficial ways. More importantly, there is a concern that the educational system itself has become obsessed with professional standards losing focus of other essential aspects of teaching. There is a need to restore the balance to a standards-obsessed educational system.

Finally, there is always the concern that these standards are written by those outside of Qatar and are simply adopted by the Qatari Educational System. Problems arise when standards go unexamined or uncritically adopted from Western approaches by a different cultural group. In this case, an outside international educational consulting firm wrote the standards and teachers are expected to acculturate or assimilate to the beliefs, values, ideas and knowledge embedded in the professional standards. We would argue that adaptation should be the process used with Qatar's professional standards where the standards are adapted (make fit for, or change to suit a new purpose) to the Qatari context.

\section{Conclusion}

Professional standards are often viewed as the answer to all of the woes that affect education. Although professional standards could provide some guidance for teachers, they cannot solve the problems associated with "dysfunctional school organizations, outmoded curricula, inequitable allocation of resources, or lack of school support for children and youth" (Darling-Hammond, 1999, p. 39). From the above discussion, it is clear that this particular context has received both benefits and drawbacks from the adoption of professional teacher standards. However, it is not always evident that the teachers fully understand the discourse of standards and that the purpose of the adoption of the standards is actually evolving. Giroux (1988) calls for teachers to be intellectuals and this is vital with professional standards because the knowledge and terms are loaded with prominent ideas and conceptions about teaching and learning. Teachers must be able to understand their own self-formation as individuals and teachers and how professional standards and the power embedded in standard-based reforms shapes their pedagogy because teaching is a process that requires the integration of thinking and practice. This is vital for educational reform and the implementation of professional standards.

\section{References:}

Andrew, M. (1997). What matters most to teacher educators. Journal of Teacher Education, 48(3), 167-176. http://dx.doi.org/10.1177/0022487197048003002

Anderson, G. L. (2001). Disciplining leaders: A critical discourse analysis of the ISLLC national examination and performance standards in educational administration. International Journal of Leadership in Education, 4(3), 199-216. http://dx.doi.org/10.1080/13603120110062699

Bowker, G., \& Star, S. L. (1999). Sorting things out: Classification and its consequences. Cambridge, MA: MIT Press.

Brewer, D. J., Augustine, C. H., Zellman, G. L., Ryan, G. W., Goldman, C. A., Stasz, C., \& Constant, L. (2007). Education for a new era: Design and implementation of $k-12$ education reform in Qatar. Rand Corp: Santa Monica, CA. Retrieved October 14, 2013 from: http://www.rand.org/pubs/monographs/MG548/

Bullough, R. V., \& Goldstein, S. L. (1984).Technical curriculum form and American elementary-school art education. Journal of Curriculum Studies, 16(2), 143-154. http://dx.doi.org/10.1080/0022027840160204

Cohen, L., Manion, L., \& Morrison, K. (2007). Research methods in education (6th ed.). Oxford, UK: Routledge Publishers. 
The impact of Qatar national professional standards: Teachers' perspectives

Darling-Hammond, L. (2004). Standards, accountability, and school reform. Teachers College Record, 106(6), 1047-1085. http://dx.doi.org/10.1111/j.1467-9620.2004.00372.x

Darling-Hammond, L. (2003). The effects of initial teacher education on teacher quality. Paper presented at the Australian Council for Educational Research (ACER) Research Conference, Melbourne.

Darling-Hammond, L. (2000). Teacher quality and student achievement: A review of state policy evidence. Seattle, WA: Center for the Study of Teaching and Policy, University of Washington.

Darling-Hammond, L. (1999). Reshaping teaching policy, preparation and practice: Influences on the National Board for Teaching Professional Standards. Washington: AACTEPublications.

Ewenstein, B., \& Whyte, J. (2009). Knowledge practices in design: The role of visual representations as 'epistemic objects.' Organization Studies, 30(1), 7-30. http://dx.doi.org/10.1177/0170840608083014

Giroux, H. A., \& McLaren, P. (1996). Teacher Education and the Politics of Engagement: The Case for Democratic Schooling. In P. Leistyna, A. Woodrum, \& S. A. Sherblom (Eds.), Breaking free: The transformative power of critical pedagogy (pp. 301-331). Cambridge, MA: Harvard Educational Review.

Giroux, H. A. (1988). Teachers as intellectuals: Toward a critical pedagogy of learning. Cambridge, MA: Bergin and Garvey Publishers.

Gordon, L., \& Whitty, G. (1997). Giving the 'hidden hand' a helping hand? The rhetoric and reality of neoliberal education reform in England and New Zealand. Comparative Education, 33(3), 453-467. http://dx.doi.org/10.1080/03050069728460

Greenhough, B. (2007). Situated knowledges and the spaces of consent. Geoforum, 38, 1140-1151. http://dx.doi.org/10.1016/j.geoforum.2007.02.008

Hargreaves, A. \& Shirely, D. (2009). The fourth way: The inspiring future of educational change. Thousand Oaks, CA: Corwin Press.

Hursh, D. (2001) Neoliberalism and the control of teachers, students, and learning: The rise of standards, standardization and accountability. Cultural Logic, Special Issue: Marxism and Education, 4(1). Retrieved November 8, 2013, from: http://www.eserver.org/clogic/4-1/4-1.html

Ingvarson, L. (1998). Teaching standards: Foundations for professional development reform. In A. Hargreaves, A. Lieberman, M. Fullan \& D. Hopkins (Eds.), International handbook of educational change (pp. 1006-1033). Dordrecht: Kluwer.

Kleinhenz, E., \& Ingvarson, L. (2004). Teacher accountability in Australia: Current policies and practices and their relation to the improvement of teaching and learning. Research Papers in Education, 19(1), 31-49. http://dx.doi.org/10.1080/0267152032000176963

Kostogriz, A. (2007). Political dimensions of teacher professionalism and professional learning. Introduction. In A. Berry A. Clemans \& A. Kostogriz (Eds.), Dimensions of professional learning (pp. 1-4). Rotterdam: Sense Publishers.

Mahony, P., \& Hextall, I. (2000). Reconstructing teaching: Standards, performance and accountability. London: Routledge/Falmer.

Mcdaid, K. (2010). Professional standards and professional learning: A position paper. Retrieved November 5 , 2013 from: http://www.merga.net.au/documents/MERGA33_McDaid.pdf

McLaren, P. (2007). Life in schools: An introduction to critical pedagogy in the foundations of education (5th ed.). Boston: Allyn and Bacon.

Mulcahy, D. (2010). Assembling the 'accomplished' teacher: The performativity and politics of professional teaching standards. Educational Philosophy and Theory, 43(1), 94-113.

Online Qatar (2009). Professional license system introduced for teachers in Doha. Retrieved October 5, 2013 from:

http://www.onlineqatar.com/614-Professional-license-system-introduced-for-teachers-in-Doha.html

Phillips, L. (1998). The third wave of modernization in Latin America: Cultural perspectives on neoliberalism. Lanham, MD: Rowman \& Littlefield.

Qatar National Professional Standards for Teachers and School Leaders. (2007). Doha, Qatar: Education Institute. 
Romanowski, M. H. \& Amatullah, T.

Sachs, J. (2005, August). Professional standards: quality teachers for the future. Speech presented at the Sharing Experience: Ways Forward on Standards Conference, Melbourne.

Sachs, J. (2003). Teacher professional standards: Controlling or developing teaching? Teachers and Teaching, 9(2), 175-186. http://dx.doi.org/10.1080/13540600309373

Santiago, P. (2002). Teacher demand and supply: Improving teaching quality and addressing teacher shortages. Paris: Organisation for Economic Co-operation and Development (OECD). http://dx.doi.org/10.1787/232506301033

Supreme Education Council. (2011). Above 30 \% teachers not qualified. Retrieved October 5, 2013 from: http://www.thepeninsulaqatar.com/qatar/163929-above-30pc-teachers-not-qualified.html

Supreme Education Council. (2007). National professional standards: Creating a benchmark for excellence in teaching. Retrieved October 5, 2013 from: http://www.sec.gov.qa/En/Media/News/Pages/NewsDetails.aspx?NewsID=2436

Thrupp, M. (2006). Professional standards for teachers and teacher education: Avoiding the pitfalls. Waikato: New Zealand Post Primary Teachers' Association.

Tuinamuana, K. (2011). Teacher professional standards, accountability, and ideology: Alternative discourses. Australian Journal of Teacher Education, 36(12). http://dx.doi.org/10.14221/ajte.2011v36n12.8

Yinger, R. (1987). Learning the language of practice. Curriculum Inquiry, 17, 293-318. http://dx.doi.org/10.2307/1179695

Zuzovsky, R., \& Lipman, Z. (2006). Standards of teaching and teaching tests: Is this the right way to go? Studies in Educational Evaluation, 32, 37-52. http://dx.doi.org/10.1016/j.stueduc.2006.01.006 